\title{
PENGAMATAN JENIS-JENIS IKAN DI PERAIRAN SUNGAI MUSI SUMATERA SELATAN
}

\author{
Syamsul Bahri*) \\ *Teknisi Litkayasa pada Balai Riset Perikanan Perairan Umum, Palembang
}

Teregristasi I tgl. 19/5/2005; Disetujui terbit tgl. 11/1/2007

\section{PENDAHULUAN}

Indonesia memiliki potensi sumber daya perairan umum, sungai, dan rawa demikian luas yang tersebar di beberapa pulau terutama di Sumatera, Kalimantan, dan Irian Jaya. Sungai Musi sebagai sungai yang terpanjang dan terluas di Sumatera, ditinjau dari segi perikanan mempunyai peranan yang penting sebagai sumber protein hewani bagi masyarakat, mata pencaharian nelayan dan lain-lain.

Menurut Pollnac dan Malvestuto (1991) menyatakan bahwa pencemaran Sungai Musi lebih berat dibandingkan dengan Sungai Kapuas. Dikatakan bahwa sumber daya perikanan Sungai Musi sudah banyak mendapat tekanan ekologis dari luar terutama pembangunan sektor pertanian dan industri yang berakibat langsung terhadap kehidupan ikan. Industriindustri tersebut seperti industri pengolahan minyak bumi dan petrokimia Pertamina, industri pupuk Pusri, industri kayu lapis, industri minyak sawit, pabrik pengolahan karet, HPH, perkebunan, dan lain-lain yang diperkirakan buangan limbahnya mempunyai dampak negatif terhadap sumber daya ikan.

Perairan sungai di bagian tengah terkenal dengan keragaman jenis ikan yang tinggi namun juga terdapat tekanan ekologis. Di sisi lain, perairan sungai terutama di bagian hilir merupakan daerah pertemuan antara air laut dengan air tawar dan banyak habitat yang menjadi tempat terjebaknya nutrient sehingga daerah perairan ini relatif lebih subur (Odum 1971). Perairan bagian hilir merupakan daerah asuhan benihbenih ikan, terutama jenis-jenis ikan yang bermigrasi seperti ikan patin dan udang galah.

Perairan sungai bagian hilir mempunyai sifat yang agak berbeda dengan bagian hulu dan tengah. Aliran air tidak selalu berjalan ke satu arah tetapi di bagian ini terjadi fluktuasi pasang surut yang dipengaruhi oleh dinamika pergerakan air laut di daerah estuaria. Penumpukan bahan pencemaran yang diakibatkan oleh limbah industri sekitar, besar kemungkinan akan terjadi. Sehingga kerusakan habitat hidup ikan ada di wilayah perairan ini.

Ikan merupakan sumber daya perairan umum yang mempunyai potensi cukup besar untuk memenuhi kebutuhan protein hewani maupun sebagai penyumbang devisa negara. Pentingnya sumber daya hayati bagi bangsa Indonesia tidak diragukan lagi, di mana pertumbuhan penduduk sangat cepat, sedangkan sumber daya alam (ikan) di perairan umum semakin terbatas jumlahnya.

Tujuan penulisan makalah ini untuk mengetahui jenis-jenis ikan di perairan Sungai Musi bagian hulu, tengah, dan hilir pada tahun 2002.

\section{BAHAN DAN METODE}

Bahan yang digunakan adalah: 1) ikan sampel, 2) kantong plastik, 3) formalin 10\%, 4) karet gelang, 5) spidol, 6) note book, 7) ballpoint, 8) mistar, 9) timbangan, dan 10) disectingset 1 unit.

Penelitian dilaksanakan dengan menggunakan metode survei lapangan. Pengambilan contoh sampel empat kali mencakup musim kemarau dua kali, yaitu bulan Juni dan Juli 2002 serta musim penghujan dua kali, yaitu bulan September dan November 2002. Letak stasiun sampling ditentukan berdasarkan pertimbangan topografi dan pemanfaatan lahan oleh berbagai aktivitas manusia. Stasiun pengamatan berjumlah 15 lokasi di Sungai Musi yang mewakili zona hulu, tengah, hilir, dan di anak sungainya. 
Contoh sampel didapat dari nelayan dengan berbagai aktivitas alat tangkap, contoh sampel dimasukkan dalam kantong plastik lalu diberi pengawet formalin $10 \%$. Selanjutnya dibawa ke laboratorium Biologi BRPPU untuk di identifikasi berdasarkan buku identifikasi dari Kotelat et al., 1993.

\section{HASIL}

Jenis-jenis ikan yang berhasil ditemukan pada perairan sungai selama kegiatan penelitian tahun 2002 dan telah diidentifikasi berjumlah \pm 86 jenis dari 22 famili dan 3 jenis udang (Tabel 1). Jenis ikan yang termasuk dalam famili Cyprinidae merupakan yang terbanyak. Berdasarkan distribusi geografis, Ondara 1992 mengatakan bahwa jenis ikan air tawar asli mendominasi perairan tawar Sumatera dan Kalimantan adalah jenis ordo Ostariophysi (Cyprinid dan Siluroid), Labirinthyci (Anabantid dan Ophicephalid), ordo Percomorphi (famili nandidae), ordo Opistomi (Mastacembelidae), dan ordo Malacopterygii (Nototeridae). Zona Musi bagian tengah

Tabel 1. Jenis-jenis ikan yang teridentifikasi di perairan Sungai Musi selama penelitian

\begin{tabular}{|c|c|c|c|c|c|c|}
\hline \multirow{2}{*}{ No } & \multirow{2}{*}{ Nama Daerah } & \multirow{2}{*}{ Nama IImiah } & \multirow{2}{*}{ Familia } & \multicolumn{3}{|c|}{ Zona Penyebaran } \\
\hline & & & & Hulu & Tengah & Hilir \\
\hline 1 & Betok & Anabas testudineus & Anabantidae & - & + & + \\
\hline 2 & Gurame & Osphronemus guramy & Anabantidae & - & + & + \\
\hline 3 & Petek & Stenops vittatus & Anabantidae & - & - & + \\
\hline 4 & Baung & Mystus sabanus & Bagridae & + & ++ & + \\
\hline 5 & Baung jaksa & Macrones wyckii & Bagridae & + & + & - \\
\hline 6 & Baung akar & Mystus olynodes & Bagridae & + & + & + \\
\hline 7 & Biji duren/baung munti & Bagroides melapterus & Bagridae & - & + & - \\
\hline 8 & Baung buntak & Mystus wolfii & Bagridae & - & + & + \\
\hline 9 & Beringit & Mystus planiceps & Bagridae & - & + & + \\
\hline 10 & Ikan duri & Arius venosus & Bagridae & - & - & + \\
\hline 11 & Layang-layang & Bagrichthys macracanthuss & Bagridae & - & + & - \\
\hline 12 & Merundu/lundu & Mystus gulio & Bagridae & - & + & + \\
\hline 13 & Tikusan/tiang layar & Bagrichthys hypselopterus & Bagridae & - & + & - \\
\hline 14 & Sepat siam & Tricogaster pectoralis & Belontiidae & - & ++ & + \\
\hline 15 & Sepat merah mato & Tricogaster tricopterus & Belontiidae & - & ++ & + \\
\hline 16 & Lais timah & Cryptopterus schilbeides & Biluridae & - & + & + \\
\hline 17 & Bujuk & Channa melanopterus & Channidae & - & + & + \\
\hline 18 & Gabus & Channa striata & Channidae & - & ++ & + \\
\hline 19 & Sepengkah & Ambassis gemnochepalus & Channidae & - & + & - \\
\hline 20 & Toman & Channa mikroleptes & Channidae & - & ++ & + \\
\hline 21 & Keli pendek & Clarias teijmanni & Clariidae & - & + & + \\
\hline 22 & Keli panjang & Enchhelolarias tapeinopterus & Clariidae & - & + & + \\
\hline 23 & Kalang & Clarias meladerma & Clariidae & - & + & + \\
\hline 24 & Keli mata dacing & Clarias niouchofii & Clariidae & - & + & + \\
\hline 25 & Kejubang & Botia macrocanthus & Cobitidae & + & + & - \\
\hline 26 & Langli hitam & Botia hymenophysa & Cobitidae & + & + & - \\
\hline 27 & Langli bulan & Botia reversa & Cobitidae & + & + & - \\
\hline 28 & Ikan lidah & Cynoglossus sp & Cynoglossidae & - & + & + \\
\hline 29 & Aro merah mato & Osteochilus melanoplaura & Cyprinidae & - & + & + \\
\hline 30 & Bawal putih & Pampus orgenteus & Cyprinidae & - & + & + \\
\hline 31 & Bilis & Rasbora lateristriata & Cyprinidae & - & - & + \\
\hline 32 & Cawang hidung & Schistorynchusheterorynchus & Cyprinidae & + & - & - \\
\hline 33 & Cengkak & Tor tambroides & Cyprinidae & + & - & - \\
\hline 34 & Gegali/maliki/kerali & Labcheilos & Cyprinidae & + & + & - \\
\hline 35 & Ikan elang & Puntius tetrazona & Cyprinidae & + & + & + \\
\hline 36 & Ikan haji & Puntius anchisporus & Cyprinidae & - & + & - \\
\hline 37 & Juar & Luciosoma trinema & Cyprinidae & - & + & + \\
\hline 38 & Sebarau & Hampala macrolepidota & Cyprinidae & + & ++ & + \\
\hline 39 & Kepras & Puntioplites waandersi & Cyprinidae & - & + & + \\
\hline 40 & Kepah & Barbodes sp & Cyprinidae & - & + & - \\
\hline 41 & Kepiat & Barbodes gonionotus & Cyprinidae & - & + & + \\
\hline 42 & Kerali & Labocheilos falcifer & Cyprinidae & + & + & - \\
\hline 43 & Lambak & Dangila ocelata & Cyprinidae & + & ++ & + \\
\hline 44 & Lampam & Barbodes schwanefeldii & Cyprinidae & + & ++ & + \\
\hline 45 & Lemajang & Cyclolochelichtys enoplos & Cyprinidae & - & + & + \\
\hline 46 & Lumapako & Thynichthys polylepis & Cyprinidae & - & + & + \\
\hline
\end{tabular}


Lanjutan Tabel 1 ...

\begin{tabular}{|c|c|c|c|c|c|c|}
\hline \multirow{2}{*}{ No } & \multirow{2}{*}{ Nama Daerah } & \multirow{2}{*}{ Nama IImiah } & \multirow{2}{*}{ Familia } & \multicolumn{3}{|c|}{ Zona Penyebatan } \\
\hline & & & & Hulu & Tengah & Hilir \\
\hline 47 & Maliki & Lobacheilos $s p$ & Cyprinidae & - & + & - \\
\hline 48 & Mentulu & Barbichtyseleapis & Cyprinidae & + & + & - \\
\hline 49 & Meriko/Puntung hanyut & Balantiocheilos melanopterus & Cyprinidae & - & + & + \\
\hline 50 & Palau & Osteochilus hassektii & Cyprinidae & - & + & + \\
\hline 51 & Selusur Batang & Epalzorphynthus hallopterus & Cyprinidae & - & + & - \\
\hline 52 & Selimang & Crossocheilos oblongus & Cyprinidae & + & + & - \\
\hline 53 & Selimang bangkung & Chrossocheilos & Cyprinidae & - & + & - \\
\hline 54 & Semuringan & Puntius fasciatus & Cyprinidae & - & + & - \\
\hline 55 & Seputih & Lobocheilos bo & Cyprinidae & - & + & - \\
\hline 56 & Senggiringan & Puntius fasciatus & Cyprinidae & - & + & - \\
\hline 57 & Siamis & Chela oxygaster & Cyprinidae & + & + & + \\
\hline 58 & Sihitam & Labeo chryssophekadion & Cyprinidae & + & + & + \\
\hline 59 & Umbut & Cyclochelichthis repasson & Cyprinide & - & + & - \\
\hline 60 & Ringau & Thunnichthys thynoides & Cyprinide & - & + & + \\
\hline 61 & Coli & Albulichthys albuloides & Cyprinide & - & + & + \\
\hline 62 & Buntal laut & Diodon hystrik & Diodontidae & - & - & + \\
\hline 63 & Ikan pirang & Setipinna malanochir & Engraulididae & - & + & - \\
\hline 64 & Parang-parang & Coilia lindmani & Engraulididae & - & + & + \\
\hline 65 & Sapil tembakang & Helostoma temminckii & Helostomatidae & - & ++ & + \\
\hline 66 & Julung-julung & Zenarchopterus sp & Hemirhamphidae & - & + & + \\
\hline 67 & Piluk & Macrognatus acileatus & Mastacembelidae & - & + & - \\
\hline 68 & Tilan & Mastecembulus unicolor & Mastacembelidae & + & + & - \\
\hline 69 & Belida & Chitala lopis & Notopteridae & - & + & + \\
\hline 70 & Putak & Notopterus notopterus & Notopteridae & - & + & + \\
\hline 71 & Udang galah & Macrobracium rosenbergii & Palemonidae & - & + & ++ \\
\hline 72 & Juaro & Pangasius polyunarodon & Pangasidae & - & + & + \\
\hline 73 & Patin & Pangasius jambal & Pangasidae & + & + & + \\
\hline 74 & Patin lubuk & Pangasius nasutus & Pangasidae & - & ++ & + \\
\hline 75 & Riu & Pangasius macronema & Pangasidae & - & + & - \\
\hline 76 & Sembilang & Plotosius canius & Plotosidae & - & + & + \\
\hline 77 & Ikan janggut & Polynemus longipectoralis & Polynemidae & - & + & ++ \\
\hline 78 & Kepar/sepatung & Pristolepis fasciata & Pristolepididae & - & + & + \\
\hline 79 & Udang abang & Metanpenaeus monoceros & Sargastidae & - & - & ++ \\
\hline 80 & Udang pipih & Metanpenaeus brevicornis & Sargestidae & - & - & + \\
\hline 81 & Gulame & Sciaena russelti & Sciaenidae & - & + & + \\
\hline 82 & Ikan timah & Kryptopterus apogon & Siluridae & - & + & - \\
\hline 83 & Lais & Kryptopterus sp & Siluridae & - & + & - \\
\hline 84 & Sengarat & Belodontichtys dinema & Siluridae & - & + & + \\
\hline 85 & Tapa & Wallago leerii & Siluridae & - & + & + \\
\hline 86 & Dalum & Bagarius yerelli & Sisoridae & + & - & - \\
\hline 87 & Buntal asa & Tetraodon palembangensis & Tetraodontidae & - & + & + \\
\hline 88 & Layur & Trichiurus savala & Trichiuridae & - & - & + \\
\hline 89 & Pari & Dasyatis bleeker & Trygomidae & - & - & + \\
\hline
\end{tabular}

Keterangan:

- = tidak ada $++=$ sedang

$+=$ sedikit +++ banyak

merupakan zona yang banyak terdapat jenis ikannya, hal ini disebabkan pada zona Musi bagian tengah terdapat berbagai tipe habitat yang cocok sebagai tempat hidup berbagai jenis ikan tawar, tercatat ada \pm 76 jenis. Di bagian hilir ditemukan \pm 58 jenis, dan pada Sungai Musi bagian hulu ditemukan \pm 20 jenis. Jenis ikan yang terdapat di ketiga zona ada \pm 8 jenis (Tabel 1). Kedelapan jenis ikan tersebut termasuk jenis ikan yang dapat bermigrasi jauh (longitudinal migration) (Welcome, 1985), dan umumnya dari kelompok ikan putih (whitefish) yang biasa hidup di perairan sungai.

\section{PENUTUP}

Jenis-jenis ikan di perairan Sungai Musi berdasarkan daerah penyebarannya: Zona hulu 20 jenis, zona tengah 76 jenis, dan zona hilir 58 jenis. Jenis ikan yang berbeda di tiga zona \pm 8 jenis yaitu jenis ikan yang termasuk ikan putih (whitefish) yang dapat bermigrasi jauh (longitudinal migration).

Untuk menjaga kelestarian ikan, maka beberapa bagian hutan rawa (rawang) di zona tengah dan beberapa bagian hutan mangrove di zona hilir diupayakan agar jadi areal suaka perikanan (reservat ikan).eregristasi I tgl. 19/5/2005 


\section{DAFTAR PUSTAKA}

Kottelat, M., J.A Whitten, N. Kartikasari, \& S. Wiryoatmojo. 1993. Freshwater fishes of Western Indonesia and Sulawesi. Periplus Edition and EMDI Project Indonesia, Jakarta. $221 \mathrm{p}$.

Odum, E.P. 1971. Fundamentals of Ecology. Third Edition. W.B. Sounders Company, Toronto. 574p.
Ondara, 1992. Pemanfatan dan pengelolaan perikanan perairan lebung. Prosiding TKI. Perikanan Perairan Umum. Pusat penelitian dan Pengembangan Perikanan, Jakarta. (89-105). 231 hal.

Welcome, R.L. 1985. River fisheries. F.A.O. Fish. Tech. Paper (262), Rome. 330p. 